\title{
PERTANGGUNG JAWABAN PIDANA SEORANG DOKTER DALAM TINDAKAN PEMBEDAHAN
}

\author{
Oleh: T. Vaison Siahaan \\ tobavaison@ymail.com \\ Universitas Kristen Indonesia, Jakarta, Indonesia
}

\begin{abstract}
The doctor's profession is noble in the midst of people's lives. A doctor in his work is directly related to the efforts of healing and suffering of patients. So that not a few people who are resigned to the doctor, even though the doctor because of the actions of medical services he did harm his side. On the other hand, as a result of increasing public legal awareness, including their rights and obligations in the eld of health services, it is not uncommon for a doctor at the green table to take responsibility for his actions. Such responsibilities can be either civil or criminal.
\end{abstract}

Keywords: doctor; healing and suffering; medical services; criminal.

\section{Pendahuluan}

Profesi dokter adalah suatu profesi yang dianggap mulia di tengah masyarakat. Karena dia dengan pekerjaannya berhubungan langsung dengan penyembuhan seseorang dari penyakit yang dideritanya atau paling tidak mengurangi penderitaan yang dialaminya. Akibatnya, bagi kalangan awam timbul anggapan bahwa dokter itu tidak mungkin berbuat salah dalam menjalankan tugasnya, kendatipun dokter bukan seorang nabi. Sehingga mereka biasanya bersifat pasrah pada seorang dokter yang dipercayainya.

Pada era belakangan ini terdapat kecenderungan bahwa anggota masyarakat sudah semakin kritis untuk menilai setiap hal-hal yang terjadi di masyarakat. Kesadaran hukum anggota masyarakat semakin meningkat. Akibatnya, akhir-akhir ini dapat disaksikan tidak sedikit orang atau pasien yang berani untuk menggugat atau balikan mengajukan dokter ke meja hijau akibat kesalahan profesi atau kesalahan tindakan medis yang dilakukannya.

Kalau ditinjau lebih lanjut, dalam menjalankan fungsinya di tengah-tengah kehidupan masyarakat, dokter mempunyai kedudukan yang unik. Ada beberapa ciri yang perlu diperhatikan dalam kaitannya dengan etik, yaitu ${ }^{1}$ :

- Rasa takut sering merupakan latar belakang utama kedatangan pasien kepada dokter. Betapapun adanya keluhan itu sendiri tidak riel, tetapi rasa takut itu benar-benar riel. Untuk membebaskan diri dari bayangan yang menakutkan itu, seseorang akan bersedia mengorbankan apapun juga, kecuali jiwanya.

- Pasien sepenuhnya berserah diri kepada dokter. Bahkan dalam keinginannya bebas dari rasa sakit, ia bersedia "disakiti" oleh dokternya, misalnya melalui prosedur diagnostik ataupun tindakan operasi.

- Hubungan antara dokter dengan pasien bersifat sangat pribadi. Seluruh rahasia yang dimilikinya akan dibukakan kepada dokter jika dikehendaki.

- Dokter bekerja dalam situasi yang serba tidak pasti. Selain sifat-sifat tubuh manusia yang sangat bervariasi dokter tidak dapat berbuat seperti halnya seorang montir yang boleh membongkar seluruh isi objek yang diperbaiki, hanya untuk memastikan letak dan macam kelainan yang menimbulkan keluhan.

\footnotetext{
1 Ninik Mariyanti, SH, Malapraktek Kedokteran. Dari Segi Hukum Pidana Dan Perdata, Penerbit Bina Aksara, Jakarta,1988, hal. 1-2.
} 
- Masyarakat menaruh harapan dan kepercayaan kepada dokter tetapi sekaligus juga mencurigai dan balikan cemburu terhadapnya.

Tuntutan fungsi sosial terhadap profesi kedokteran sangat liesar, bahkan mungkin terbesardiantara profesi-profesi lainnya. Ini merupakan beban mental yang berat bagi para dokter yang dalam hidup sehariharinya justru diperlukan sebagai "objek ekonomi".

Hubungan fungsional antara dokter dengan masyarakat memberikan status yang unik, tetapijuga tinggi bagi dokter. Mereka yang bermental lemah akan mudah terbuai oleh status ini dan lupa diri”.

\section{Tanggung Jawab Pidana}

Seiring dengan semakin meningkatnya kesadaran hukum mas3'arakat, dalam perkembangan selanjutnya timbul permasalahan menyangkut pertanggung jawaban pidana seorang dokter, khususnya .yang berhubungan dengan kelalaian yang didasarkan kepada teori-teori kesalahan dalam hukum pidana.

Pertanggung jawaban pidana seorang dokter baru timbul apabila terlebih dahulu dapat dibuktikan adanya kesalahan profesional, seperti kesalahan dalam diagnosa atau kesalahan dalam cara-cara pengobatan/ perawatan. Untuk menentukan adanya kesalahan profesional dalam pemeriksaan sidang pengadilan nantinya diperlukan pendapat para ahli yang dapat memberikan data akurat kepada Hakim. Tentu saja kesalahan disini harus mempunyai hubungan sebab akibat dengan hasilnya dan mempunyai derajat-derajat tertentu.

Pertanggung jawaban pidana yang perlu dibuktikan dengan adanya kesalahan profesional itu biasanya dihubungkan dengan masalah kelalaian dan persetujuan dari pasien yang bersangkutan. Contoh : Dalam menganalisa apakah perbuatan seorang dokter mengandung pertanggung jawaban pidana atau tidak dalam melakukan pembedahan. Persoalannya adalah apakah tindakan untuk membedah seorang pasien yang dilalaikan oleh ahli bedah dapat dimasukkan sebagai penganiayaan sebagaimana dirumuskan dalam KUHP.

Pembedahan dapat dikategorikan ${ }^{2}$ :

2 Dr. Soedjono Soekanto dan Dr. Kartono Muhammad, Aspek Hukum Dan Etika Kedokteran Di Indonesia, Grafiti Press, Jakarta, 1983, hal.68.
- Pembedahan atas dasar indikasi medis yang tujuannya untuk memulihkan kesehatan pasien (seperti operasi usus buntu).

- Pembedahan tanpa indikasi medis (seperti operasi plastik untuk kepentingan kecantikan).

- Jika dihubungkan dengan persetujuan pasien, pembedahan dapat dikategorikan sebagai berikut

- Pembedahan atas dasar indikasi medis dengan adanya persetujuan pasien.

- Pembedahan atas dasar indikasi medis tanpa adanya persetujuan pasien.

- Pembedahan tanpa indikasi medis dengan persetujuan pasien.

- Pembedahan tanpa indikasi medis dan tanpa adanya persetujuan pasien.

\section{Ad.l. Pembedahan atas dasar indikasi medis dengan adanya persetujuan pasien.}

Perbuatan seorang dokter yang didasarkan kepada indikasi medis dengan adanya persetujuan pasien dapat dibenarkan dan tidak merupakan masalah (hukum). Hal ini diatur dalam undang-undang yang menentukan bahwa hak atau wewenang profesional sebagai penerapan ilmu dan ketrampilan merupakan dasar pembenaran juridis yang meniadakan sifat perbuatan melanggar hukum.

Baik doktrin maupun jurisprudensi juga membenarkan tindakan yang demikian. Yang terpenting adalah tujuan serta kesadaran akan tujuan tersebut. Lain halnya dengan penganiayaan yang menurut KUHP merupakan perbuatan yang disengaja untuk membuat cidera dan tidak didasarkan kepada tujuan yang diperbolehkan. Sepanjang tindakan pelayanan medis berapa operasi dilakukan menurut cara-cara dan tujuan profesi kedokteran, perbuatan tersebut tidak dapat dikualifikasikan sebagai tindakan pidana penganiayaan (pasal 351, $352 \mathrm{KUHP}$ ).

Sehingga dengan demikian, seorang dokter yang melakukan pembedahan tidak perlu merasa resah dan khawatir, walaupun hasilnya tidak menguntungkan si pasien, karena pelaksanaan pembedahan yang normal tidak merupakan peristiwa pidana. Pada dasarnya bahwa unsur "persetujuan" dari pasien dilihat dari 
hukum pidana bukanlah merupakan dasar umum bagi pengecualian terjadinya peristiwa pidana. Namun dalam beberapa hal, "persetujuan" dimaksud dapat meniadakan sifat melanggar hukum, seperti ${ }^{3}$ :

- Pelanggaran terhadap hak-hak yang terbuka bagi umum (melukai lawan dalam pertandingan tinju).

- Dalam tindakan pembedahan seperti yang diuraikan di atas.

\section{Ad.2. Pembedahan atas dasar indikasi medis tanpa adanya persetujuan pasien.}

Pasal 89 KUHP mengemukakan bahwa membuat orang pingsan atau tidak berdaya disamakan dengan menggunakan kekerasan.

Berdasarkan bunyi pasal tersebut dalam kaitannya dengan pembedahan tanpa persetujuan pasien dapatlah dikatakan bahwa dokter yang melakukan pembedahan atas dasar indikasi medis tetapi tanpa persetujuan pasien, telah melakukan kekerasan sebagaimana diatur dalam pasal 89 KUHP. Dalam hal ini dapat dilihat bahwa fungsi persetujuan pasien sangat penting artinya, karena dengan persetujuan tersebut pasien terlindungi dari tindakan sewenang-wenang dokter, yang tidak mustahil dapat terjadi dan mengakibatkan adanya gangguan terhadap diri si pasien.

Dengan demikian dalam tindakan medis yang demikian, apabila terjadi gangguan-gangguan pada pasien (cacat) atau meninggal, maka dokter yang bersangkutan harus bertanggung jawab atas tindakannya tersebut.

\section{Ad.3. Pembedahan tanpa indikasi medis den- gan adanya persetujuan pasien.}

Apabila dianalisa berdasarkan kerangka acuan tersebut di atas, yakni persetujuan pihak pasien dalam tindakan pembedahan untuk tujuan medis dapat meniadakan tanggung jawab pidana seorang dokter, maka kalau hasil pembedahan itu tidak menimbulkan hal-hal yang negatif (atau tindakan pembedahan berhasil), maka tidak masalah. Permasalahan hukum adalah manakala pembedahan itu gagal, maka dokter yang bersangkutan tetap harus mempertanggung jawabkan perbuatannya.

3 Soerjono Soekanto, SH, MH, Tanggung Jawab Dokter Dalam melaksanakan Profesinya, Medika No. 12 tahun 1981.
Alasannya adalah bahwa kita harus lebih menitikberatkan kepada tugas keprofesionalannya seorang dokter dalam menjalankan pekerjaannya, sehingga segi medisnya lebih diutamakan daripada harus melihat faktor persetujuan pasien. Pembedahan tanpa indikasi medis tidak semutlak harus dilakukan seperti halnya pembedahan atas dasar indikasi medis (misalnya operasi usus buntu) karena yang disebut belakangan ini lebih cenderung untuk harus dilaksanakan demi kesembuhan dan kesehatan. Sedangkan pembedahan tanpa indikasi medis (misalnya bedah plastik untuk kecantikan) tidak merupakan suatu keharusan untuk dilaksanakan, karena tidak berkaitan dengan penyembuhan penyakit.

Jadi jelasnya bahwa seorang dokter yang melakukan pembedahan tanpa indikasi walau sekalipun disetujui oleh pasien, maka apabila terjadi hal-hal yang tidak diinginkan pasien, dokter tetap harus dimintakan tanggung jawab hukum, karena persetujuan tersebut baru akan meniadakan sifat pidana apabila pembedahan itu dilakukan dengan tujuan pemulihan kesehatan (indikasi medis).

\section{Ad.4. Pembedahan tanpa indikasi medis dan tanpa adanya persetujuan pasien.}

Untuk jenis tindakan yang demikian, sudah jelas bahwa tindakan tersebut merupakan tindak pidana yang harus dipertanggung jawabkan, dan dapat dituduh telah melakukan penganiayaan sebagaimana diatur dalam pasal 89 jo 251 KUHP.

\section{Kesimpulan}

Walaupun tugas seorang dokter adalah mulia karena berhubungan langsung dengan kesehatan dan keselamatan hidup manusia, berupa penyembuhan seseorang dari penyakit yang dideritanya, tetapi di lain pihak tidak tertutup kemungkinan adanya orang-orang tertentu (pasien) yang mengajukan dokter ke meja hijau akibat suatu tindakan medis yang dia lakukan.

Seorang dokter tidak perlu merasa khawatir dalam melaksanakan tugas keprofesionalannya, sepanjang dokter yang bersangkutan dapat melaksanakan tugasnya sesuai dengan etik-etik profesinya sebagai tuntutan profesionalisme seorang dokter. 
Tô-râ: Volume 4 Nomor 1, April 2018, T. Vaison Siahaan, hal. 89-92

\section{Daftar Pustaka}

Atang Ilyas Ranoemihardja R, Ilmu

Kedokteran Kehakiman (Forensic

Science), Tarsito Bandung, 1983.

Fred Amein, Hukum Kesehatan Suatu

Pengantar, Simposium Hukum

Kedokteran di Jakarta, 6-7 Juni 1983.

Moelyatno Prof. SH, Kitab Undang

Undang Hukum Pidana, Bina

Aksara Jakarta, 1983.

Soerjono Soekanto, Dr, SH.MA dan

Kartono Muham- mad, Dr., Aspek

Hukum Dan Etika Kedokteran di

Indonesia, Grafiti Press, Jakarta, 1983.

\section{, Faktor-Faktor Yang \\ Mempen- garuhi Penegakan}

Hukum, CV Rajawali Jakarta, 1982.

Majalah Medika No. 12 Desember 1981.

Majalah Tempo No. 35 Tahun XVI 25 Oktober 1986. 